\title{
Elemental Concentration in Serpentinitic Soils over Ultramafic Bedrock in Sierra Bermeja (Southern Spain)
}

\author{
Ana Romero-Freire ${ }^{1,2} * \mathbb{E}$, José Antonio Olmedo-Cobo ${ }^{3} \mathbb{C}$ and José Gómez-Zotano ${ }^{3}$ \\ 1 Departamento de Edafología y Química Agrícola, Facultad de Ciencias, Universidad de Granada (UGR), \\ 18071 Granada, Spain \\ 2 Departamento de Oceanografía, Grupo Bioxeoquímica Mariña, Instituto de Investigación \\ Mariñas (IIM-CSIC), 36208 Vigo, Spain \\ 3 Departamento de Análisis Geográfico Regional y Geografía Física, Facultad de Filosofía y Letras, \\ Universidad de Granada (UGR), 18011 Granada, Spain; jaolmedo@ugr.es (J.A.O.-C.); \\ jgzotano@ugr.es (J.G.-Z.) \\ * Correspondence: anaromero@iim.csic.es
}

Received: 29 August 2018; Accepted: 9 October 2018; Published: 12 October 2018

\begin{abstract}
Although the presence of potentially toxic metals in soils is normally associated with human soil pollution, these elements also appear naturally in environments in which the lithological base contains ultramafic rocks such as peridotites. Serpentinitic soils tend to develop on substrates of this kind, often containing metals with few or no known biological functions, which in some cases are toxic for most plants. This study assessed the level of potentially toxic metals and other elements in an endorheic basin discovered in Sierra Bermeja (Southern Spain), one of the largest peridotite outcrops on Earth. In this location-of particular interest given that basins of this kind are very rare on peridotites-six geomorphoedaphic sub-units on three different substrates were identified. The distribution of microelements in these sub-units was analyzed, and stratified random sampling was performed to identify the major ions with essential functions for living organisms and the potentially toxic metals. The lowest values for macronutrients appeared in the soils formed on ultramafic materials. When analyzing the load of potentially toxic metals, no significant differences were detected between the soils formed on serpentinite and peridotite substrates, although different values were obtained in the soils formed over acidic rocks.
\end{abstract}

Keywords: ultramafic rocks; Mediterranean peridotites; serpentinite; potentially toxic metals; geomorphoedaphic units; Sierra Bermeja

\section{Introduction}

Although peridotite rocks appear all over the world and represent about $13 \%$ of global geological substrates [1,2], they are often regarded as one of the most peculiar rock types on Earth because of their chemical composition [3]. Nowadays, soil contamination by metals is a matter of great concern worldwide [4-6], and is usually the result of human activities, as observed for example by References [7-10]. However, some of the potentially toxic metals in soils are of natural origin and are produced by both mechanical and chemical weathering of the original serpentinite. The soil that forms above this material has a high content in some of the microelements that influence its formation [2,11]. Specifically, serpentinitic soils formed on peridotite rocks are often of ecological importance due to the fact that they typically have low calcium-to-magnesium ratios, low nutrient levels (phosphorus, nitrogen and potassium), and high levels of potentially toxic metals (PTM), such as nickel, chromium, iron and cobalt [12,13], often in association with other major elements 
$(\mathrm{Al}, \mathrm{Mg}, \mathrm{Fe} . .$.$) [14,15]. The serpentinitic soils that form on peridotites are usually rich in Ni, Co,$ $\mathrm{Cr}, \mathrm{Fe}, \mathrm{Mn}, \mathrm{Zn}$, and $\mathrm{Cu}$, and generally have a much higher content of these metals than nearby soils on different substrates [16-18]. The most important metal pools in soils include exchangeable and organically bound metals, metals associated with Mn and Fe-oxides, and metals inside mineral structures [4]. Another problem is that ultramafic soils are generally deficient in essential plant mineral nutrients and major cations [19]. Although some metals are considered to be essential micronutrients for living organisms, in large amounts they can be biologically toxic [14]. This infrequent (peridotites are rarely found on Earth) combination of metals produces a similar unusual biological component in the soils formed over those rocks, which in turn leads to the emergence of a large number of endemic species especially adapted to the toxic elements [20-22]. As a result, ultramafic areas have become a high priority for biodiversity and ecosystem conservation $[19,23]$.

The recent discovery of an undisturbed ultramafic depression in Sierra Bermeja (Betic Cordillera, Southern Spain) has provided a new natural laboratory, free of anthropogenic influence, in which the relationship between surface modeling and the potentially toxic metal load in the resulting soils can be studied. This is especially interesting given the exceptional nature of this type of geomorphological environment within ultramafic outcrops under Mediterranean conditions. Although little research has so far been done on this question in the Mediterranean basin [24] and in other parts of the world [25,26], researches in this endorheic area could provide interesting insights into geochemical and soil formation processes on peridotite rocks at a local scale. For example, the residence time of elements normally depends on the climate and can vary greatly from one place to another [27], however in an endorheic area, metal migration is much more limited, which means that the primary mineral composition plays an essential role in soil formation.

The aim of this research is to provide data about major and microelements present in undisturbed mountain soils located in an endorheic area, recently discovered by the authors in the Sierra Bermeja ultramafic massif and relate them to the different substrates, and the resulting morphologies observed. Element background concentrations will allow us to obtain a better understanding of the geochemical process of soil formation above this rock material. The fact that this area belongs to the Nature 2000 network and is therefore considered a valuable European habitat, is another reason why it is of great interest for researchers.

\section{Materials and Methods}

Study area. The study area is located in Sierra Bermeja, a mountain range that forms part of the western end of the Betic Cordillera (Southern Spain) (Figure 1 top left). It is a coastal massif of medium altitude (1508 masl, Cerro Abanto) which covers an area of $300 \mathrm{~km}^{2}$, making it one of the largest peridotite outcrops on the planet [28]. The specific location of the study is an endorheic basin, recently discovered by the authors, situated near the line of peaks of the Sierra Palmitera, a mountainous pyramidal extension of the main massif with orientation $\mathrm{N}$ to $\mathrm{S}$, at an altitude of between 1432 and 1364 masl, ( $\left.36^{\circ} 35^{\prime} 53^{\prime \prime} \mathrm{N}, 5^{\circ} 03^{\prime} 21^{\prime \prime} \mathrm{W}\right)$ (Figure 1 right).

The study area has a Mediterranean climate typical of medium-altitude coastal mountains, where its altitude and closeness to the Mediterranean Sea play a crucial role [29]. The altitude factor means that it has quite high annual precipitation levels for the Mediterranean region ( $>1000 \mathrm{~mm} /$ year) and mild average temperatures (an estimated $1{ }^{\circ} \mathrm{C}$ in the study area). The coastal influence, associated with the peculiar wind regime in the Strait of Gibraltar, gives the climate a semi-oceanic character [30], in which cryptoprecipitation (associated with frequent orographic clouds in the summer in this coastal region) plays an important role. In this context and considering the available climate data, it was estimated that there was an inferior supramediterranean bioclimatic level above about 1200 masl, which developed under a lower humid ombrotype [29].

In biogeographical terms, and in accordance with the sectorization of the Betic chorological province proposed by Reference [31], the Sierra Bermeja range belongs to the Bermejense district of the Rondeño sector. In this range, there are two large forest domains, the edapho-xerophile pine 
forests of Pinus pinaster, to which the study area belongs, and the climatophile fir forests of Abies pinsapo. The dominant vegetation in the endorheic basin today is characterized by the development of two clearly distinguishable bush and brush formations, which appear over the granite materials and peridotite substrates, respectively [29,32]. Firstly, there is a small copse of Quercus rotundifolia bushes - a relict species in Sierra Bermeja-on the leucogranites, whilst on the peridotites there are different facies of scrubland made up above all of Cistus ladanifer, C. populifolius, and C. salvifolius and of Genista lanuginosa and Ulex baeticus. Lastly, there is a field of annual grasses (Poa, Trifolium, Festuca, Asphodelus, etc.) which grow on the regosol type soil at the bottom of the basin. This soil formation is boosted by the edaphic nitrification provided by local fauna (above all wild boar, Sus scrofa), and the occasional presence of livestock. Paleo-populations of Abies pinsapo were also discovered in this area [33].

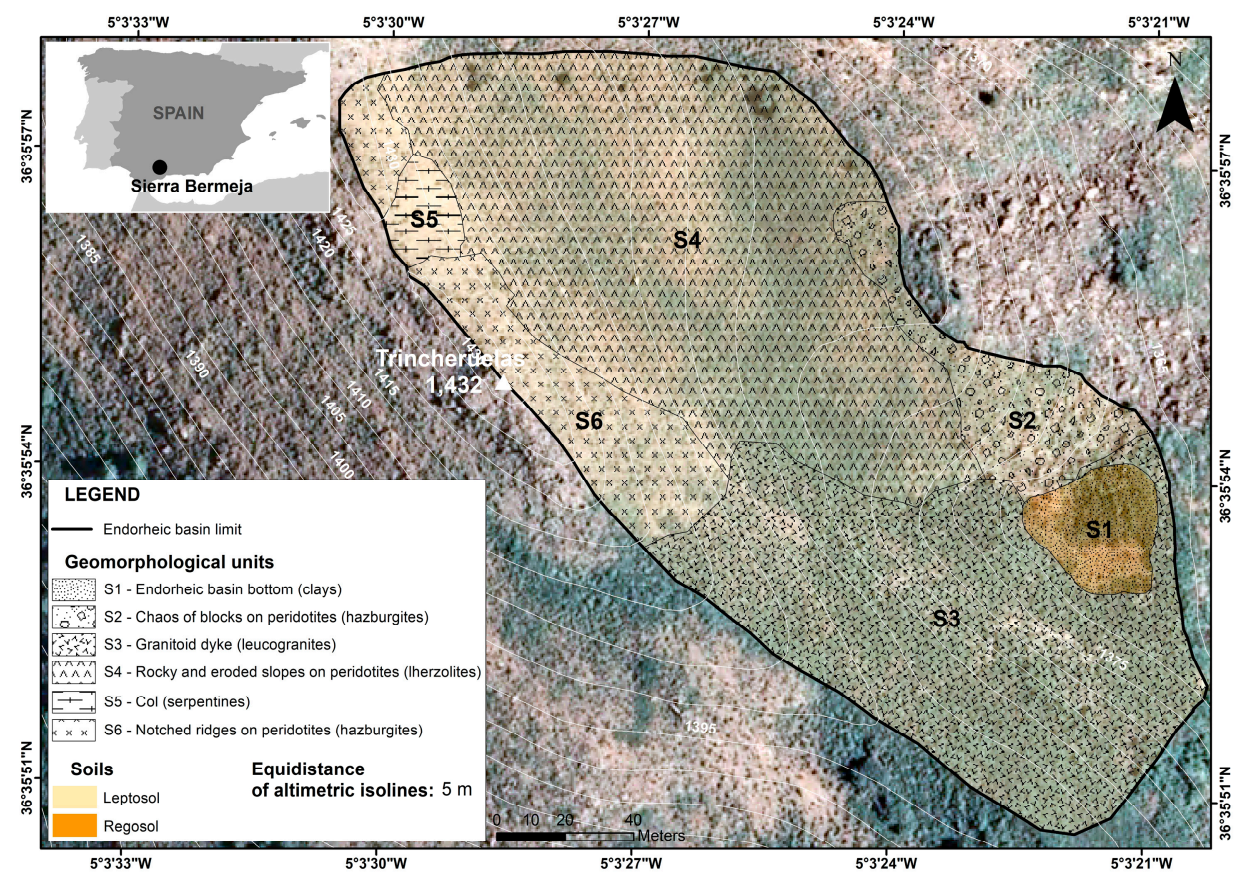

Figure 1. Location of Sierra Bermeja in southern Spain (top left) and of the geomorphological units and soils (S1-S6) sampled in the area.

Geomorphoedaphic characterization of the endorheic basin. Aerial photographs were used for the identification of the study area. These photographs, which were obtained from the National Geographic Institute of Spain [34], were taken in 2012 near the line of peaks of Sierra Palmitera in the Sierra Bermeja massif. Given that the existing topographic cartography did not show the presence of a depression, we revisited the place several times between 2013 and 2017 to corroborate the existence of the endorheic basin. Detailed mapping was carried out using a Geographic Information System (GIS), and using the most recent aerial photographs (date of flight 07-2013) and an altimetric vector layer with an equidistance of $2 \mathrm{~m}$ obtained from the digital terrain model of Spain. These materials are available at the cartographic repository of the National Geographic Institute of Spain [34]. This topographic cartography presents a graphic output of altimetric isolines with an equidistance of $5 \mathrm{~m}$, taken from the digital terrain model of Spain.

The geomorphoedaphic analysis was carried out combining field work and photointerpretation, which allowed us to identify, characterize, and map (scale 1:5000) the main geoforms and their corresponding soil units (Figure 1 right). The general geological information was taken from the existing bibliography and the Geological Map of Spain (scale 1:50,000) [35]. With this information and on-site observations, we established the lithological composition, structure, and disposition of the different rock units and the corresponding soil types. 
Sampling and chemical analyses. The selection of soil samples in the field was based on the parent material and the area accessibility of the six sub-units identified. Stratified random sampling was performed in each of these six units. After removing the Ah horizon, soil samples from the surface horizons below $(<20 \mathrm{~cm})$ were collected and georeferenced. In some cases, the difficult access to the area prevented us from taking paired samples. Even so, samples were taken from at least 3 points in each unit.

The soil samples were air-dried at $25^{\circ} \mathrm{C}$ and sieved (2-mm mesh). The $\mathrm{pH}$ (soil:water ratio 1:2.5) and electrical conductivity (EC) (soil:water ratio 1:5) were analysed according to standard methods [36]. The total concentration of microelements and other soil constituents was analysed in the laboratory by PXRF with a portable X-ray fluorescence analyser NITON XLt 792, with a $40 \mathrm{kV}$ X-ray tube containing an Ag anode target excitation source, and a Silicon PIN-diode [37]. The following elements were obtained in $\mathrm{mg} \mathrm{kg}^{-1}$ : $\mathrm{Ca}, \mathrm{Co}, \mathrm{Cr}, \mathrm{Cu}, \mathrm{Fe}, \mathrm{K}, \mathrm{Mn}, \mathrm{Ni}, \mathrm{Zn}$, and $\mathrm{Sr}$. The selected testing time for each lamp was $120 \mathrm{~s}$. As a standard reference, nine replicates of Certified Reference Soil Material (CRM052-050) were also measured by PXRF, according to Reference [38]. Recoveries of all studied elements were $89 \pm 19 \%$ (average \pm standard deviation).

Statistical analyses. Descriptive statistics of the units were calculated to check their normality (individual histogram, mean, median, minimum, maximum, and quartiles), and Levene's test was conducted to check the homogeneity of variances. Significant differences were determined by ANOVA (Tukey's test). The microelements with significant differences were represented by untransformed boxplots. The SPSS 20.0 software package (SPSS, Chicago, IL, USA) was used in these statistical analyses of the dataset. The relative distribution of the microelements in the different sub-units was obtained by non-metric multidimensional scaling (NMDS) and the Pearson correlation. Simple regression analyses were performed using the R statistical package 3.2.5 (R Development Core Team 2016). For the statistical analysis all replicates were used $(n=27)$, and the statistical significance level was 0.05 in all cases.

\section{Results and Discussion}

\subsection{Geomorphoedaphic Division of the Study Area}

The endorheic basin has an area of $0.3 \mathrm{~km}^{2}$. It has an NW-SE orientation and an altitudinal gradient of $68 \mathrm{~m}$, reaching 1432 masl at the highest point and 1364 masl at its bottom. The slopes range from flat and moderately steep to steep.

In this basin, which is exceptional in geomorphological terms in all the peridotite outcrops in Southern Spain, three lithological units were identified: Peridotites (lherzolites with plagioclase and harzburgites partially serpentinized by metamorphic process), Serpentinites, and Leucogranites. Although it has been impossible to establish the age of these materials based on the existing bibliography, according to Reference [39], it is considered that the Sierra Bermeja mountain complex has an age of $22 \mathrm{Ma}$. These rock complexes have given rise to clearly differentiable modelling units in the endorheic basin, for which we identified 6 geomorphoedaphic sub-units, as shown in Figure 1, right: The bottom of the endorheic basin (clays, regosol-S1), disordered rock blocks ("chaos of blocks") on peridotites (hazburgites, leptosol-S2), a granitoid dyke (leucogranites, leptosol-S3), rocky and eroded slopes on peridotites (lherzolites, leptosol-S4), a col (serpentinites, leptosol-S5), and notched ridges on peridotites (hazburgites, leptosol-S6). The most important geophysical characteristics of these sub-units are set out in Table 1.

On the one hand, the peridotite outcrop ( $64.9 \%$ of the area of the basin) was characterized by the presence of diverse geoforms, i.e., the lherzolitas produce stony eroded slopes (unit S4), while notched crests and a chaos of large heterometric blocks were formed over the harzburgites with the longest axis of up to 8-10 m (units S2 and S6). In addition and coinciding with a fault which crosses the basin in a NW-SE direction, the facies of harzburgites appeared more serpentinized. Chrysotile (asbestos) appears frequently aligned around the axis of the fault, which is resolved in the drainage divide 
through the formation of a col (unit S5). The geomorphological differences between peridotites and serpentinites coincided with those detected by Reference [40]. The frequent rocky outcrops showed abundant quantities of joint sets, characteristic of these ultramafic rocks. Together with the fault network, this explains the strong fracturing of the rock and the large colluviums that have developed on the edge of the basin. The reddish crust of serpentinite, generated by the peridotite altered by atmospheric agents, has a high iron oxide load and covers the original green of the rock across the outcrop. This atmospheric serpentinization also affects the micro-modelling of the rock (serpentinitic microkarst), which appears to be standing on end due to the bright angular crystals of the pyroxenes, which are more resistant to erosion.

Table 1. Main characteristics and soil identification of the six geomorphoedaphic sub-units sampled.

\begin{tabular}{ccccccc}
\hline $\begin{array}{c}\text { Geomorphoedaphic } \\
\text { Sub-Unit }\end{array}$ & $\begin{array}{c}\text { Number of } \\
\text { Samples } \mathbf{( n )}\end{array}$ & $\begin{array}{c}\text { Parent } \\
\text { Material }\end{array}$ & $\begin{array}{c}\text { Extension } \\
\mathbf{( m}^{\mathbf{2}} \mathbf{n}\end{array}$ & $\begin{array}{c}\text { Elevation } \\
\mathbf{( m a s})\end{array}$ & Orientation & $\begin{array}{c}\text { Soil } \\
\text { Taxonomy }\end{array}$ \\
\hline $\begin{array}{c}\text { S1-Endorheic basin } \\
\text { bottom }\end{array}$ & 3 & Clays & 1110 & $1368-1364$ & Southeast & $\begin{array}{c}\text { Regosol } \\
\text { Dystric }\end{array}$ \\
\hline S2-Chaos of blocks & 3 & $\begin{array}{c}\text { Peridotites } \\
\text { (Hazburgites) }\end{array}$ & 2138 & $1393-1367$ & Southeast & $\begin{array}{c}\text { Leptosol } \\
\text { Lithic }\end{array}$ \\
\hline S3-Granitoid dyke & 5 & Leucogranites & 9980 & $1414-1367$ & East & $\begin{array}{c}\text { Leptosol } \\
\text { Mollic }\end{array}$ \\
\hline $\begin{array}{c}\text { S4-Rocky and } \\
\text { eroded slopes }\end{array}$ & 5 & $\begin{array}{c}\text { Peridotites } \\
\text { (Lherzolites) }\end{array}$ & 13,261 & $1428-1377$ & Southeast & $\begin{array}{c}\text { Leptosol } \\
\text { Eutric }\end{array}$ \\
\hline S5-Col & 6 & Serpentinites & 538 & $1430-1421$ & East & $\begin{array}{c}\text { Leptosol } \\
\text { Eutric }\end{array}$ \\
\hline S6-Notched ridges & 5 & $\begin{array}{c}\text { Peridotites } \\
\text { (Hazburgites) }\end{array}$ & 2989 & $1432-1424$ & East & $\begin{array}{c}\text { Leptosol } \\
\text { Eutric }\end{array}$ \\
\hline
\end{tabular}

Lastly, a granitoid dyke acidic vein intrusion composed of quartz-feldspar (leucogranites, unit S3) occupied $33.3 \%$ of the study area, and obliquely cuts the foliation and the banded formation of the peridotites in a NW-SE direction, just like the other vertical veins of acidic rocks from Sierra Bermeja, coinciding with the large breaks in the ultramafic outcrop [41]. The rock outcrops on the surface and is characterized by its hardness, pure white color, and external appearance of fine-to-coarse grain granite.

A small flat area measuring $1100 \mathrm{~m}^{2}$ (1.8\% of the total area, unit S1) has formed at the bottom of the depression due to the accumulation of clay material. Despite the fact that there is no drainage, the surface showed no signs of saturation (cracked earth or grey soil horizon, hygrophilous vegetation), which reinforces the hypothesis about a bed of colluvial origin that makes water infiltration easier. The surface analysis of the structure and the morphology of the deposit sealing the bottom of the basin would seem to rule out a glacial origin (terminal moraine), as evidence of periglaciation has only been found at about 800-1000 masl in coastal limestone massifs near Sierra Bermeja (periglacial kartstogenesis, deposits of grèzes litées, breccias, scree, and éboulis) [42]. The homogeneity of the rocky material (leucogranites) and the absence of peridotites, despite the outcrops upstream, were signs that the deposit has been transported over a very short distance. Similar results can be obtained from detailed observation of the morphology of the clasts, with sharp edges and no evidence of wear. Lastly, the possibility that the origin of the basin was related with the karstification processes that affected other ultramafic areas with a tropical-subtropical climate during the mid-Miocene cannot be ruled out [24].

In addition to the morphological consequences arising from its particular lithology and its unusual endorheic nature, given the proven impermeability of ultramafic rocks [43], the main physiographical features of the basin resulted from a feature of structural origin. Specifically, a network of listric faults that cross the basin in a NW-SE direction and generate successive steps and flats which run downwards from North to South. The last of these, due to an intersection of the fault system and in accordance with the observations made during this research, forms a depression which is closed by the intruded dyke in the peridotites, which obstructs its drainage via a series of colluviums. 


\subsection{Soil Characterization on the Different Geomorphological Units}

The unique environmental conditions in the study area favor unusual geochemical processes of rock weathering and soil genesis [29]; the weathering of serpentine minerals from peridotite rocks leads to the formation of serpentinitic soils of little potential, in which leptosol soil types dominate (Figure 2); whilst other regosol types are only found in the colluvial area at the bottom of the basin (unit S1). The first group of soils extends widely across the slopes of the depression and has developed both on leucogranites (unit S3) and on the two facies of peridotites identified (hazburgites on units S2 and S6, and lherzolites on unit S4), as well as on the col formed on serpentinites that makes up unit S5 (see Table 1). The external erosion processes (enhanced by an irregular precipitation regime with occasional torrential downpours), consolidated material, and steep slopes all contribute to the constant rejuvenation of the soil despite the dense vegetation. Three types of leptosols were identified: Lithic, Eutric, and Mollic. These typologies have various common features: An absence of carbonates, rockiness, and lateral discontinuities caused by numerous outcrops. The lithic leptosols are normally no more than $10 \mathrm{~cm}$ deep and appear on the surfaces most affected by erosion (unit S2). In the other positions, eutric leptosols appeared when they reached depths of $30 \mathrm{~cm}$ (units S4, S5, and S6). In the most sheltered areas with the densest vegetation (the holm-oak wood on leucogranites, unit S3), leptosols can develop with a mollic epipedon of less than $30 \mathrm{~cm}$. The regosols for their part appeared at the bottom of the basin on unconsolidated material (unit S1) of colluvial origin, with more than $20 \%$ of fine earth within the $50 \mathrm{~cm}$ closest to the surface. In the profile obtained when taking the samples, we observed that this soil evolved from the formation of heterometric granulite stones (longest axis measuring 6-60 cm) embedded in a red clayey matrix. They have an ochric epipedon in which no diagnostic horizons can be distinguished. The acidic $\mathrm{pH}$ (Table 2) categorizes this soil as dystric [44].

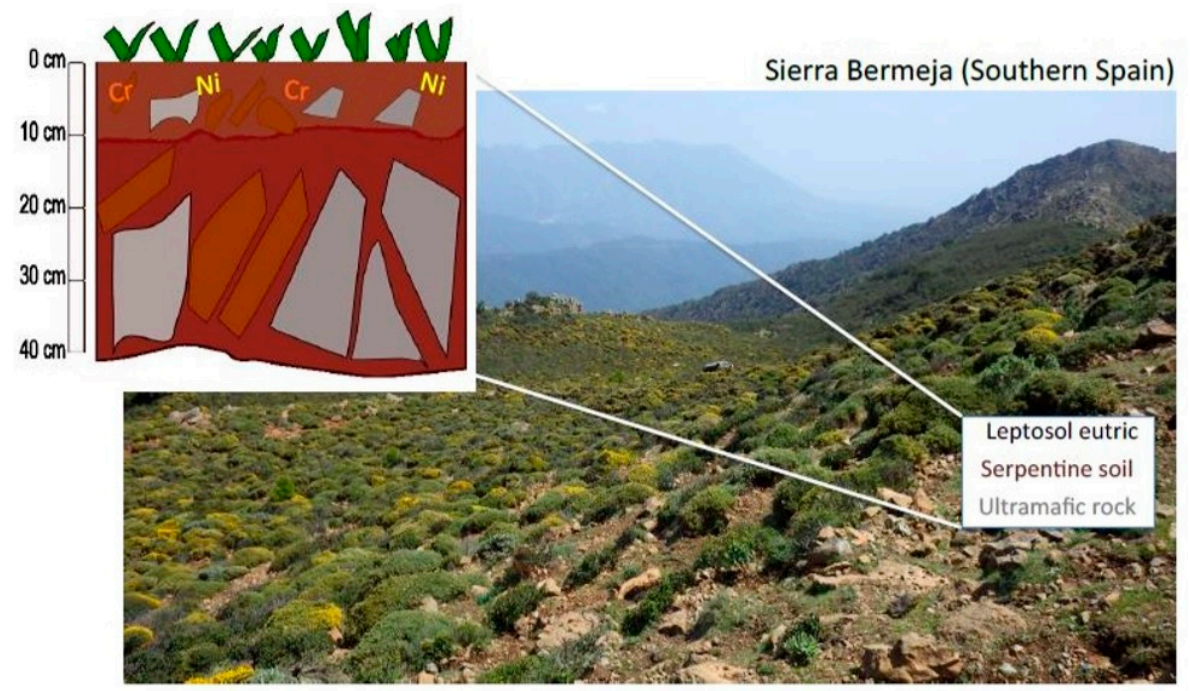

Figure 2. Graphic representation of prevailing soil types in the study area.

The chemical composition and the main properties of a particular soil depend upon the geological material from which it derived [5]. Serpentine soil profiles usually have neutral to sub-alkaline $\mathrm{pH}$, which increases in line with depth. The acidic $\mathrm{pH}$ value found at some sites could be due to rock weathering $[45,46]$. The data obtained from the surface surveys (Table 2) show increasing levels of $\mathrm{pH}$ from the bottom of the basin (S1-S3) up to its outer limits on peridotites characterized by basic $\mathrm{pH}$ levels. The $\mathrm{pH}$ values in S5 and S6 (col on serpentinites and hazburgite facies in ridge formation) were around 7, a typical value for slightly basic-neutral soils. However, the high precipitation rates in the bioclimatic level in that area helped to wash the soils, thereby increasing the acid level. The most acidic values, of around six, appeared on the clays at the bottom of the basin and in the leucogranites 
(units S1 and S3, respectively). Soil samples showed low electrical conductivity values, with no marked differences between them, which indicates that they were not saline $\left(E C<0.2 \mathrm{dS} \mathrm{m}^{-1}\right)$.

Table 2. Mean values for $\mathrm{pH}$, electric conductivity, concentration of major elements $(\mathrm{Ca}, \mathrm{K}, \mathrm{Fe})$, and ratio Sr:Ca for the six sampling sub-units (S1-S6) \pm STD and minimum and maximum values (min-max). Letters on the right of numbers mean significant differences between samples (Tukey, $p<0.05$ ).

\begin{tabular}{|c|c|c|c|c|c|c|}
\hline Geomorphoedaphic & \multirow{2}{*}{$\mathrm{pH}$} & EC & $\mathrm{Ca}$ & $\mathbf{K}$ & $\mathrm{Fe}$ & Sr:Ca \\
\hline Sub-Unit & & $\mathrm{dS} \mathrm{m}^{-1}$ & \multicolumn{4}{|c|}{$\mathrm{mg} \mathrm{kg}^{-1}$} \\
\hline $\begin{array}{c}\mathrm{S} 1 \\
(\mathrm{n}=3)\end{array}$ & $\begin{array}{l}6.05 \pm 0.12 \\
(5.96-6.18)\end{array}$ & $\begin{array}{l}0.08 \pm 0.01 \\
(0.07-0.12)\end{array}$ & $\begin{array}{c}13,000 \pm 2400 \mathrm{bc} \\
(10,600-15,400)\end{array}$ & $\begin{array}{c}8360 \pm 1217 \mathrm{bc} \\
(7144-9577)\end{array}$ & $\begin{array}{c}73817 \pm 32704 \mathrm{bc} \\
(42,612-107,838)\end{array}$ & $0.0036 \pm 0.0011$ \\
\hline $\begin{array}{c}\mathrm{S} 2 \\
(\mathrm{n}=3)\end{array}$ & $\begin{array}{l}6.31 \pm 0.32 \\
(5.98-6.62)\end{array}$ & $\begin{array}{l}0.13 \pm 0.04 \\
(0.08-0.15)\end{array}$ & $\begin{array}{c}14,733 \pm 4362 \mathrm{bc} \\
(10,200-18,900)\end{array}$ & $\begin{array}{c}4501 \pm 904 \mathrm{ab} \\
(3794-5519)\end{array}$ & $\begin{array}{l}65,544 \pm 13,036 \text { abc } \\
\quad(54316-79,841)\end{array}$ & $0.0010 \pm 0.0002$ \\
\hline $\begin{array}{c}\text { S3 } \\
(\mathrm{n}=7)\end{array}$ & $\begin{array}{c}6.01 \pm 0.12 \\
(5.8-6.1)\end{array}$ & $\begin{array}{l}0.08 \pm 0.01 \\
(0.07-0.09)\end{array}$ & $\begin{array}{c}5434 \pm 4899 a \\
(525-12,200)\end{array}$ & $\begin{array}{c}11,012 \pm 3945 \mathrm{c} \\
(6882-18,700)\end{array}$ & $\begin{array}{c}36,213 \pm 10,299 \mathrm{a} \\
(25,300-54,807)\end{array}$ & $0.0503 \pm 0.0568$ \\
\hline $\begin{array}{c}\text { S4 } \\
(\mathrm{n}=5)\end{array}$ & $\begin{array}{l}6.39 \pm 0.13 \\
(6.21-6.51)\end{array}$ & $\begin{array}{l}0.08 \pm 0.01 \\
(0.06-0.09)\end{array}$ & $\begin{array}{l}16,920 \pm 3144 b \\
(12,900-21,700)\end{array}$ & $\begin{array}{c}6053 \pm 2380 \mathrm{ab} \\
(3154-9745)\end{array}$ & $\begin{array}{c}95,726 \pm 22,956 \mathrm{c} \\
(65,932-126,300)\end{array}$ & $0.0009 \pm 0.00042$ \\
\hline $\begin{array}{c}\text { S5 } \\
(\mathrm{n}=6)\end{array}$ & $\begin{array}{l}7.12 \pm 0.23 \\
(6.84-7.39)\end{array}$ & $\begin{array}{l}0.08 \pm 0.01 \\
(0.06-0.10)\end{array}$ & $\begin{array}{c}8376 \pm 844 \mathrm{ab} \\
(6848-9312)\end{array}$ & $\begin{array}{c}2614 \pm 617 \mathrm{a} \\
(1929-3742)\end{array}$ & $\begin{array}{c}58408 \pm 6042 \mathrm{ab} \\
(50,190-66,382)\end{array}$ & $0.0009 \pm 0.000317$ \\
\hline $\begin{array}{c}\text { S6 } \\
(\mathrm{n}=5)\end{array}$ & $\begin{array}{l}6.79 \pm 0.22 \\
(6.53-7.09)\end{array}$ & $\begin{array}{l}0.08 \pm 0.01 \\
(0.06-0.09)\end{array}$ & $\begin{array}{c}9337 \pm 1632 \mathrm{ab} \\
(7896-12,000)\end{array}$ & $\begin{array}{c}3966 \pm 591 \mathrm{ab} \\
(3297-4904)\end{array}$ & $\begin{array}{c}81,651 \pm 14,508 \text { bc } \\
(62,197-96,051)\end{array}$ & $0.0013 \pm 0.00033$ \\
\hline
\end{tabular}

X-ray fluorescence analyser equipment was used to measure the microelements in the soils. Only 3 elements with essential functions for living organisms were identified ( $\mathrm{Fe}, \mathrm{Ca}$, and $\mathrm{K})$. Calcium ranged from 5434 (S3) to 16,920 (S4); K from 2614 (S5) to 11,012 (S3), and Fe from 36,123 (S3) to 95,726 (S4) $\mathrm{mg} \mathrm{kg}^{-1}$. Tukey's test $(p<0.05)$ showed significant differences among the soil samples for all three elements. According to soil types, sample S1, more evolved soil (regosol), showed generally high concentrations of $\mathrm{Ca}, \mathrm{K}$, and $\mathrm{Fe}$, although without extreme differences compared to the other soils (leptosols). Soil sample S3, formed above granitoid material, showed the lowest Ca and Fe content, and the highest in K, even though the leptosols, due their poor edaphic maturity, have poor K levels [47]. These high values of K in S3, suggested the existence of particle transport from the granitic soil nearby, given the $\mathrm{K}$ levels in ultramafic rocks from mantle are usually below $1000 \mathrm{ppm}$ and these lower concentrations were reported before in the Serranía de Ronda (where Sierra Bermeja belongs) [48]. The $\mathrm{K}$ levels in S3 were higher than in the regosol in S1. The lowest K levels, with significantly lower values than the other samples, appeared in S5 (soil above serpentinites). These low levels of macronutrients, such as $\mathrm{K}$, are as expected in this type of soil [49]. The highest concentrations of $\mathrm{Ca}$ (and $\mathrm{Fe}$ ) appeared in the leptosol in S4, above lherzolites, a material generally formed by groups of olivine and pyroxene. According to Reference [40], because Ca is generally lost in the serpentinization process, serpentinitic parent material (S5) has less calcium than peridotite parent materials. For $\mathrm{Fe}$, although statistically significant differences were found between the different soil samples (Table 2) (highest content in S4 and lowest in S3), the values obtained were within the typical iron concentration range reported in soil, i.e., from 20,000 to $550,000 \mathrm{mg} \mathrm{kg}^{-1}$ [50]. The soils that developed from peridotites with a different mineralogical composition are always rich in ferromagnesian elements, which are responsible for their strong, characteristic red color, and the fersialitization process gives rise to newly formed clays from the olivine and other accidental minerals [51]. Reference [40] also found that these types of peridotite soil are redder than serpentinitic soils, because peridotite has more Fe (Table 2).

The Sr content was also measured, given that during soil formation Ca may be replaced by $\mathrm{Sr}$ in carbonate minerals [52]. The next step was to calculate the Sr:Ca ratio. Background concentrations of $\mathrm{Sr}$ varied from one soil unit to the other, but concentrations were less than $60 \mathrm{mg} \mathrm{kg}^{-1}$ in all units. The Sr:Ca ratio should be higher in carbonate materials than in calcareous ones. This suggests that replacement of Ca by Sr occurs much more readily in igneous rocks than in sediments, such as carbonate rocks [53]. In the samples we analyzed, the highest Sr:Ca ratio was in S3, followed by S1 (14-folder lower), whereas soil samples above peridotites showed similar lower ratios $(<0.013)$. This implied that Sr was more easily substituted by Ca in S3 [3]. 


\subsection{Potentially Toxic Metals and the Distribution of Microelements in Study Sub-Units}

The soils formed on top of ultramafic rock are characterized by a high content of potentially toxic metals. These metals are either toxic and/or have no known biological function, or can be detrimental for living organisms above certain concentrations, such as $\mathrm{Cr}, \mathrm{Ni}, \mathrm{Co}$, and $\mathrm{Cu}$. These soils also have exceptionally limited supplies of nutrients essential for biological colonization, as can be seen from the analysis of the low K concentrations in certain sampled units, and in general have a strongly xerophile character with a high propensity to erosion meaning they tend to generate weakly developed soils [51,54-56].

Figure 3 shows the potentially toxic metals (PTM) for which there were significant differences amongst the studied samples. Using Tukey's test $(p<0.05)$, results showed that the background concentration of the PTM differed significantly for the 6 studied units.
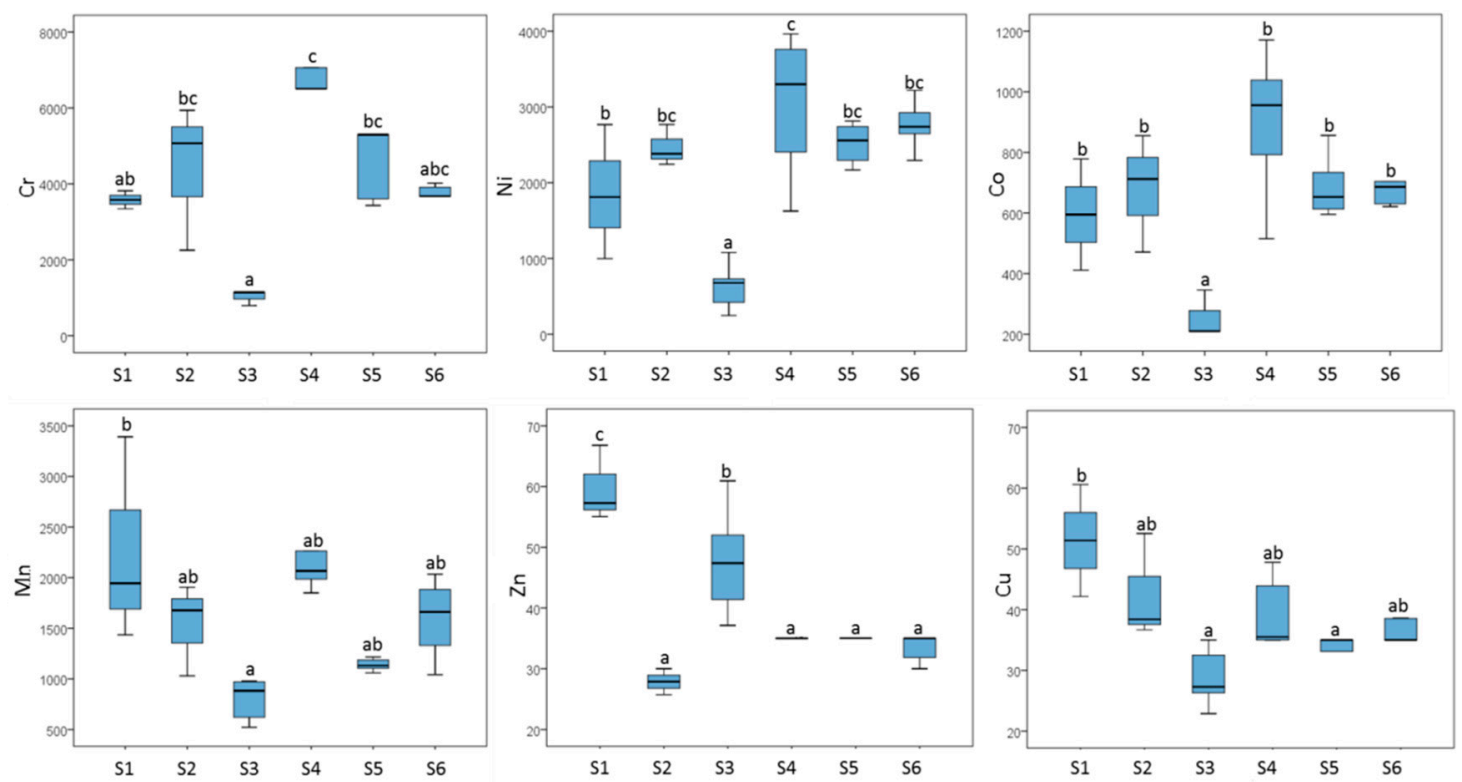

Figure 3. Boxplot for the trace elements $(\mathrm{Cr}, \mathrm{Ni}, \mathrm{Co}, \mathrm{Mn}, \mathrm{Zn}$, and $\mathrm{Cu})$ for which there were significant differences among sub-units (S1-S6). The lower and upper limits of the whiskers indicate 5\% and $95 \%$ values, respectively; boxes extend from 25 th to 75 th percentiles; horizontal lines within the boxes represent medians. Letters mean significant difference among samples (Tukey, $p<0.05$ ).

In general, the soil formed on granitic material (S3) of acidic dyke showed the lowest $\mathrm{Cr}, \mathrm{Ni}, \mathrm{Co}$, $\mathrm{Mn}, \mathrm{Cu}$, and $\mathrm{Ca}$ concentrations, and also the lower values of $\mathrm{Fe}$, which is logical considering that the rest of the units were peridotites (Fe-rich rocks), as observed in previous research by Reference [57]. Only for $\mathrm{K}$ and $\mathrm{Zn}$, the concentrations found in S3 were higher than those obtained on ultramafic rocks, which were relatively low in these elements. The soil formed on scattered fragments in the basin (S1) had a more heterogeneous mineralogical composition due to the influence of the two rocky complexes with intermediate values of $\mathrm{Co}, \mathrm{Cr}$, and $\mathrm{Ni}$, and the highest concentrations of $\mathrm{Mn}, \mathrm{Zn}$, and $\mathrm{Cu}$. These units (S3 and S1) had the most acidic pHs. As soil $\mathrm{pH}$ decreases, $\mathrm{Zn}$ adsorption becomes more significant in soils with acidic pHs (around 5-6.5), while $\mathrm{Cu}$ is less mobile and less sensitive to changes in soil $\mathrm{pH}$ than $\mathrm{Zn}$. Relative adsorption also appears in acidic conditions [58]. The oxide content is the most significant parameter in $\mathrm{Cu}$ adsorption in soils [59].

Ultramafic rocks typically have a high Fe content [32], although to the contrary, on a study done by Reference [49], they extracted soil solutions in similar environments with DTPA and they observed low content of $\mathrm{Fe}$ in the obtained solutions mainly because of higher $\mathrm{pH}$ values and competition from $\mathrm{Ni}$ and $\mathrm{Co}$, as well as low levels of macronutrients such as $\mathrm{K}$ [49]. All these characteristics were observed in the soils formed on peridotite material (S2, S4 and S6) and in the serpentinitic soil (S5). Of the soils formed on peridotite, unit $\mathrm{S} 4$ showed the highest $\mathrm{Cr}$ and $\mathrm{Ni}$ contents, with significant 
differences compared to S2 and S6. There were no significant differences between the PTM content in Unit S5 (soil formed on serpentinitic materials) and that observed for ultramafic soil. In one case (Cu), it had lower values.

In accordance with current legislation applicable in the study area [60], only the Ni contents observed in the samples formed on peridotites showed higher values than the maximum concentrations permitted for areas not designated for urban or industrial use (maximum value: $1530 \mathrm{mg} \mathrm{kg}^{-1}$ ), with averages of up to 3011 (S4). However, the Cr values were also high, more than the $2980 \mathrm{mg} \mathrm{kg}^{-1}$ identified by Reference [47] in Sierra Bermeja, and values of up to $1574 \mathrm{mg} \mathrm{kg}^{-1} \mathrm{measured}$ in soils formed on ultramafic rocks in northern Portugal [4]. These high values will have a dramatic influence on the existing vegetation made up of plants that are resistant to (or hyper-accumulators of) these elements, as identified in previous research in nearby areas by Reference [61].

The relation between the concentrations of the microelements in the studied soils and their corresponding units was investigated using Pearson correlations (Table 3) and non-metric multidimensional scaling (NMDS) ordination analysis (Figure 4). The Pearson correlations showed that the PTM (Co, Ni, Cr, and Mn) were directly correlated with each other and with Fe and Ca. Co, $\mathrm{Ni}$, and $\mathrm{Cr}$ were directly correlated with $\mathrm{pH}$ and inversely with $\mathrm{Zn}, \mathrm{K}$, and $\mathrm{Sr}$. According to the NMDS results represented in Figure 4, units S1 and S3 were randomly distributed but on the opposite side to the PTM, whereas the soils formed on peridotite had a similar distribution of metals with a direct correlation to PTM concentration. The findings for the serpentinitic soil (S5) were also of interest, in that it was inversely correlated with $\mathrm{K}$ and $\mathrm{Zn}$, although no significant differences were observed for $\mathrm{Zn}$ compared to the other units. Therefore, the high concentrations observed for $\mathrm{Co}, \mathrm{Ni}$, and $\mathrm{Cr}$ in the soils formed on peridotites (units S2, S4 and S6) and on serpentinitic pedons (S5) must be taken into consideration for the identification of possible endemic species in the study area.

In previous research in Sierra Bermeja, Reference [15] identified various subserpentinophyte species, such as Genista lanuginosa and Cistus ladanifer, that had adapted well to serpentinitic soils due to the fact that they normally grow on acidified soils; in other words, soils with low Ca concentrations [62]. This is another reason for an in-depth study of these soils and their possible relationship with the appearance of certain plant species in the ultramafic endorheic basin in Sierra Bermeja.

Table 3. Pearson correlation matrix between $\mathrm{pH}$, major ions and potential toxic metals (PTM) in the 6 sub-units of study.

\begin{tabular}{|c|c|c|c|c|c|c|c|c|c|c|c|}
\hline & \multirow{2}{*}{$\mathrm{pH}$} & \multicolumn{4}{|c|}{ Major Ions } & \multicolumn{6}{|c|}{ PTM } \\
\hline & & $\mathrm{Fe}$ & $\mathrm{Ca}$ & $\mathbf{K}$ & $\mathrm{Sr}$ & $\mathrm{Cr}$ & $\mathrm{Ni}$ & Co & Mn & $\mathrm{Zn}$ & $\mathrm{Cu}$ \\
\hline $\mathrm{pH}$ & 1 & & & & & & & & & & \\
\hline $\mathrm{Fe}$ & & 1 & & & & & & & & & \\
\hline $\mathrm{Ca}$ & & $0.525 * *$ & 1 & & & & & & & & \\
\hline K & $-0.742^{* *}$ & & & 1 & & & & & & & \\
\hline $\mathrm{Sr}$ & $-0.698^{* *}$ & $-0.585^{* *}$ & & $0.645^{* *}$ & 1 & & & & & & \\
\hline $\mathrm{Cr}$ & 0.431 * & $0.637^{* *}$ & $0.617^{* *}$ & $-0.593 * *$ & $-0.658^{* *}$ & 1 & & & & & \\
\hline $\mathrm{Ni}$ & $0.600^{* *}$ & $0.863^{* *}$ & $0.471^{* *}$ & $-0.715^{* *}$ & $-0.805^{* *}$ & $0.734^{* *}$ & 1 & & & & \\
\hline Co & $0.418 *$ & $0.831^{* *}$ & $0.508 * *$ & $-0.580^{* *}$ & $-0.769 * *$ & $0.802 * *$ & $0.901 * *$ & 1 & & & \\
\hline $\mathrm{Mn}$ & & $0.889 * *$ & $0.578 * *$ & & & $0.484^{* *}$ & $0.650 * *$ & $0.601 * *$ & 1 & & \\
\hline $\mathrm{Zn}$ & $-0.561 * *$ & & & $0.610^{* *}$ & $0.651^{* *}$ & $-0.458 *$ & $-0.556^{* *}$ & $-0.409 *$ & & 1 & \\
\hline $\mathrm{Cu}$ & & 0.412 * & & & & & & & $0.526^{* *}$ & & 1 \\
\hline
\end{tabular}

Significance: ${ }^{*}(p<0.05) ;{ }^{* *}(p<0.01)$. 


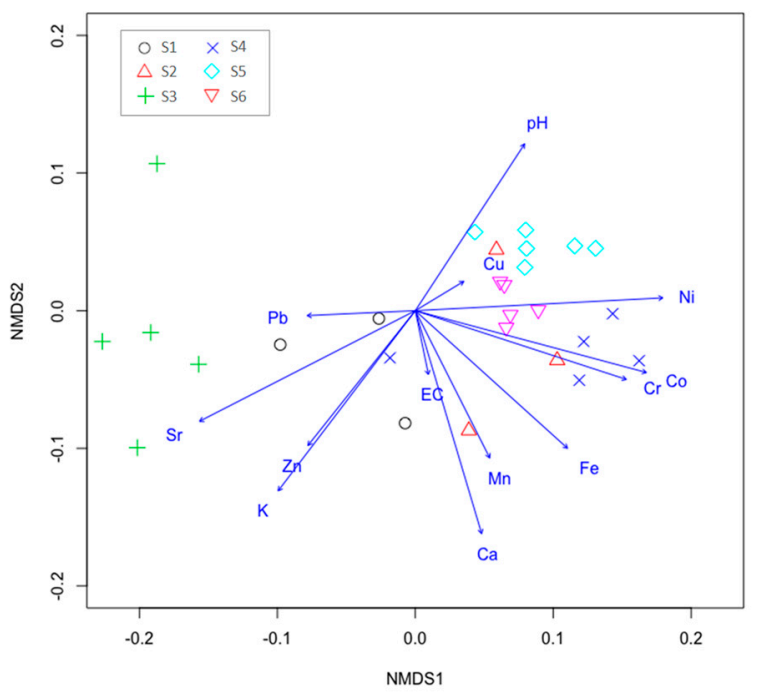

Figure 4. Non-metric multidimensional scaling (NMDS) ordination diagrams for the relationship between trace elements and studied sub-units. Lines show trace element trends; figures represent sub-units S1 to S6.

\section{Conclusions}

The recently discovered endorheic area in Sierra Bermeja (Betic Cordillera) is unique in geomorphological terms in all the peridotite outcrops in Southern Spain. This undisturbed ultramafic depression is key to understanding the relationship between surface modeling and the potentially toxic metal load in the resulting soils. Three lithological units, i.e., peridotites, serpentinites, and leucogranites, were identified in the study area, as well as six geomorphoedaphic sub-units: the bottom of the endorheic basin, disordered rock blocks on peridotites, a granitoid dyke, rocky and eroded slopes on peridotites, a col on serpentinites, and notched ridges on peridotites.

All these sub-units were characterized by the formation of weakly developed soils (mainly eutric leptosols). Our analysis showed that the soils with the lowest values for macronutrients, such as $\mathrm{K}$ and $\mathrm{Ca}$, were those on ultramafic material. This is due to the loss of these elements during the serpentinization process. However, the soil type formed directly on top of the serpentinites did not show any significant differences in terms of its content in potentially toxic metals in comparison to other soils developed on peridotites, although a change from a neutral to a slightly acidic $\mathrm{pH}$ was detected. The potentially toxic metals (PTM) $\mathrm{Co}, \mathrm{Ni}$, and $\mathrm{Cr}$ tended to appear together and there was a direct statistical correlation to this effect. These metals had a negative correlation with $\mathrm{Sr}, \mathrm{Zn}$, and $\mathrm{K}$, which are elements that act as macronutrients. The presence of these 3 major ions decreased as $\mathrm{pH}$ increased (soil on serpentines). The primary mineral composition may affect the composition of serpentinitic soil, which means that edaphic factors can have an important influence on soil biodiversity. The very weak soil development and the high quantity of potentially toxic metals may both have adverse effects on these systems, which means that an improved knowledge of metal and nutrient distribution will be crucial for a better understanding of soil formation and the establishment of vegetation on serpentinitic soils.

Future research in this area must focus on identifying the accumulation of elements, such as $\mathrm{Ni}$ and $\mathrm{Cr}$, due to their high concentrations in the vegetal stratum, so as to enable identification of species that accumulate potentially toxic metals in a study area of enormous interest in the context of the Nature 2000 network.

Author Contributions: All authors contributed equally as first authors. Specifically, the conceptualization was done by A.R.-F. and J.A.O.-C.; methodology, A.R.-F.; formal analysis, A.R.-F. and J.A.O.-C.; investigation, A.R.-F., J.A.O.-C. and J.G.-Z.; resources, A.R.-F., J.A.O.-C. and J.G.-Z.; writing-original draft preparation, A.R.-F., J.A.O.-C. and J.G.-Z.; writing-review and editing, A.R.-F. and J.A.O.-C.; supervision, A.R.-F., J.A.O.-C., and J.G.-Z.; funding acquisition, J.G.-Z. 
Funding: This research was funded by the Ministry of Economy and Competitiveness of the Government of Spain through the ULTRAFORESTS (Ref. CSO2013-47713-P) and PALEOPINSAPO (CSO2017-83576-P) Projects.

Conflicts of Interest: The authors declare no conflict of interest. The funding bodies had no role in the design of the study; in the collection, analyses, or interpretation of data; in the writing of the manuscript, or in the decision to publish the results.

\section{References}

1. Sequeira, E.M.D.; Pinto da Silva, A.R. The ecology of serpentinized areas of north-east Portugal. In The Ecology of Areas with Serpentinized Rocks; A World Review; Roberts, B.A., Proctor, J., Eds.; Kluwer Academic Publishers: Dordrecht, The Netherlands, 1991; pp. 169-197.

2. Freitas, H.; Prasad, M.N.V.; Pratas, J. Analysis of serpentinophytes from north-east of Portugal for trace metal accumulation-Relevance to the management of mine environment. Chemosphere 2004, 54, 1625-1642. [CrossRef] [PubMed]

3. Bauer, A.; Velde, B.D. Geochemistry at the Earth's Surface Movement of Chemical Elements; Springer: Berlin, Germany, 2014; ISBN 978-3-642-31359-2.

4. Díez-Lázaro, J.; Kidd, P.S.; Monterroso-Martínez, C. A phytogeochemical study of the Trás-os-Montes region (NE Portugal): Possible species for plant-based soil remediation technologies. Sci. Total. Environ. 2006, 354, 265-277. [CrossRef] [PubMed]

5. Khurana, M.P.; Jhanji, S. Influence of cadmium on dry matter yield, micronutrient content and its uptake in some crops. J. Environ. Biol. 2014, 35, 865-870. [PubMed]

6. Zhou, L.L.; Yang, B.; Xue, N.D.; Li, F.S.; Seip, H.M.; Cong, X.; Yann, Y.Z.; Liu, B.; Han, B.L.; Li, H.Y. Ecological risks and potential sources of heavy metals in agricultural soils from Huanghuai Plain, China. Environ. Sci. Pollut. Res. Int. 2014, 21, 1360-1369. [CrossRef] [PubMed]

7. Lee, C.S.; Li, X.; Shi, W.; Cheung, S.C.; Thornton, I. Metal contamination in urban, suburban, and country park soils of Hong Kong: A study based on GIS and multivariate statistics. Sci. Total. Environ. 2006, 356, 45-61. [CrossRef] [PubMed]

8. Micó, C.; Recatalá, R.; Peris, M.; Sánchez, J. Assessing heavy metal sources in agricultural soils of an European Mediterranean area by multivariate analysis. Chemosphere 2006, 65, 863-872. [CrossRef] [PubMed]

9. Yu, R.; Yuan, X.; Zhao, Y.; Hu, G.; Tu, X. Heavy metal pollution in intertidal sediments from Quanzhou Bay, China. J. Environ. Sci. 2008, 20, 664-669. [CrossRef]

10. Wang, S.L.; Xu, X.R.; Sun, Y.X.; Liu, J.L.; Li, H.B. Heavy metal pollution in coastal areas of South China: A review. Mar. Pollut. Bull. 2013, 76, 7-15. [CrossRef] [PubMed]

11. Morrison, J.M.; Goldhaber, M.B.; Mills, C.T.; Breit, G.N.; Hooper, R.L.; Holloway, J.M.; Diehl, S.F.; Ranville, J.F. Weathering and transport of chromium and nickel from serpentinite in the Coast Range ophiolite to the Sacramento Valley, California, USA. Appl. Geochem. 2015, 61, 72-86. [CrossRef]

12. Cheng, C.H.; Jien, S.H.; Tsai, H.; Chang, Y.H.; Chen, Y.C.; Hseu, Z.Y. Geochemical element differentiation in serpentine soils from the ophiolite complexes, Eastern Taiwan. Soil. Sci. 2009, 174, 283-291. [CrossRef]

13. Duivenvoorden, L.J.; Roberts, D.T.; Tucker, G.M. Serpentine geology links to water quality and heavy metals in sediments of a stream system in central Queensland, Australia. Environ. Earth. Sci. 2017, 76, 320. [CrossRef]

14. Kumar, A.; Maiti, S.K. Availability of Chromium, Nickel and Other Associated Heavy Metals of Ultramafic and Serpentine Soil /Rock and in Plants. Int. J. Emerg. Technol. Adv. Eng. 2013, 3, 256-268.

15. Pérez-Latorre, A.V.; Hidalgo-Triana, N.; Cabezudo, B. Composition, ecology and conservation of the south-Iberian serpentine flora in the context of the Mediterranean basin. Anales. Jard. Bot. Madrid. 2013, 70, 62-71.

16. Fernández, S.; Seoane, S.; Merino, A. Plant heavy metal concentrations and soil biological properties in agricultural serpentine soils. Commun. Soil Sci. Plant Anal. 1999, 30, 1867-1884.

17. Otero, X.L.; Huerta-Diaz, M.A.; Macías, F. Heavy metal geochemistry of saltmarsh soils from the Ría of Ortigueira (mafic and ultramafic areas, NW Iberian Peninsula). Environ. Pollut. 2000, 110, 285-296. [CrossRef]

18. Shah, M.T.; Ara, J.; Muhammad, S.; Khan, S.; Asad, S.A.; Ali, L. Potential Heavy Metals Accumulation of Indigenous Plant Species along the Mafic and Ultramafic Terrain in the Mohmand Agency, Pakistan. Clean Soil Air Water 2013, 42, 339-346. [CrossRef] 
19. Galey, M.L.; van der Ent, A.; Iqbal, M.C.M.; Rajakaruna, N. Ultramafic geoecology of South and Southeast Asia. Bot. Stud. 2017, 58. [CrossRef] [PubMed]

20. Wolf, A. Conservation of endemic plants in serpentine landscapes. Biol. Cons. 2001, 100, 35-44. [CrossRef]

21. Brady, K.U.; Kruckeberg, A.R.; Bradshaw, H.D.J. Evolutionary ecology of plant adaptation to serpentine soils. Annu. Rev. Ecol. Evol. Syst. 2005, 36, 243-266. [CrossRef]

22. Specht, R.L.; Batianoff, G.N.; Reeves, R.D. Vegetation structure and biodiversity along the eucalypt forest to rainforest continuum on the serpentinite soil catena in a subhumid area of Central Queensland, Australia. Austral. Ecol. 2006, 32, 394-407. [CrossRef]

23. Gómez-Zotano, J.; Román-Requena, F.; Hidalgo-Triana, N.; Pérez-Latorre, A.V. Biodiversidad y valores de conservación de los ecosistemas serpentínicos en España: Sierra Bermeja (provincia de Málaga). Boletín de la Asociación de Geógrafos Españoles 2014, 65, 187-206.

24. Rield, H.; Papadopoulou-Vrynioti, K. Comparative investigations on karst generations mainly in the Aegean Archipielago. Mitt. Naturwissenschaftlicher Ver. Für. Steiermark 2001, 131, $23-39$.

25. Graf, W.L.; Clark, S.L.; Kammerer, M.T.; Lehman, T.; Randall, I.C.; Schroeder, T.P. Geomorphlogy of heavy metals in the sediments of Queen Creek, Arizona, USA. Catena 1991, 18, 567-582. [CrossRef]

26. Gołdyn, B.; Chudzińska, M.; Barałkiewicz, D.; Celewicz-Gołdyn, S. Heavy metal contents in the sediments of astatic ponds: Influence of geomorphology, hydroperiod, water chemistry and vegetation. Ecotoxicol. Environ. Saf. 2015, 118, 103-111. [CrossRef] [PubMed]

27. McGrath, S.P. Long-term studies of metal transfer following the application of sewage sludge. In Pollutant Transport and Fate in Ecosystems; Coughtrey, P.J., Martin, M.H., Unsworth, M.H., Eds.; Blackwell Science Publications: Oxford, UK, 1987; pp. 301-317. ISBN 978-0632016273.

28. Dickey, J.S. Partial fusion products in Alpine-Type peridotites: Serranía de Ronda and other examples. Mineral. Soc. Am. 1970, 3, 33-49.

29. Gómez-Zotano, J.; Román-Requena, F.; Thorne, J.H. Attributes and roadblocks: A conservation assessment and policy review of the Sierra Bermeja. A Mediterranean serpentine landscape. Nat. Areas J. 2015, 35, 328-343. [CrossRef]

30. Gómez-Zotano, J.; Alcántara-Manzanares, J.; Martínez-Ibarra, E.; Olmedo-Cobo, J.A. Applying the Technique of Image Classification to Climate Science: The Case of Andalusia (Spain). Geograph. Res. 2016, 54, 461-470. [CrossRef]

31. Rivas-Martínez, S. Memoria del Mapa de Vegetación Potencial de España. Itiner. Geobot. 2011, 18, 5-800.

32. Gómez-Zotano, J. The broadleaved tree-conifer controversy at Sierra Bermeja, an ultramafic mountain in southern Spain. In Ultramafic Rocks: Their Soils, Vegetation and Fauna, Proceedings of the Fourth International Conference on Serpentine Ecology; Boyd, R.S., Baker, A.J.M., Proctor, J., Eds.; Science Reviews: St Albans-Herts, UK, 2004; pp. 151-156. ISBN 1900814412.

33. Olmedo-Cobo, J.A.; Cunill-Artigas, R.; Martínez-Ibarra, E.; Gómez-Zotano, J. Paleoecología de Abies sp. en Sierra Bermeja (sur de la Península Ibérica) durante el Holoceno medio a partir del análisis pedoantracológico. Bosque 2017, 259-270. [CrossRef]

34. Instituto Geográfico Nacional-IGN. Available online: http://www.ign.es/web/ign/portal/cbg-areacartografia (accessed on 14 March 2018).

35. Instituto Geológico y Minero de España-IGME Hoja 1065 MARBELLA. Available online: http:/ /info.igme. es / cartografiadigital/geologica/Magna50.aspx?language=es (accessed on 17 March 2018).

36. Ministerio de Agricultura Pesca y Alimentación-MAPA. Métodos Oficiales de Análisis. Tomo III; Secretaría General Técnica del Ministerio de Agricultura, Pesca y Alimentación: Madrid, España, 1994; ISBN 978-84-491-0003-1.

37. Martín, F.; Morales, S.; Bagur, M.G.; Estepa, C. A rapid field procedure for screening trace elements in polluted soil using portable X-ray fluorescence (PXRF). Geoderma 2010, 159, 76-82.

38. Billets, S. Innovative Technology Verification Report Xrf Technologies for Measuring Trace Elements in Soil and Sediment Niton xlt700 Series XRF Analyzer; U.S. Environmental Protection Agency: Washington, DC, USA, 2006; EPA/540/R-06/004 (NTIS PB2006-1090036).

39. Priem, H.; Hebeda, E.; Boelrijk, N.; Verdurmen, T.; Oen, I. Isotopic dating of the emplacement of the ultramafic masses in the Serrania de Ronda, Southern Spain. Contrib. Mineral. Petrol. 1979, 70, 103-109. [CrossRef] 
40. Alexander, E.B.; DuShey, J. Topographic and soil differences from peridotite to serpentinite. Geomorphology 2011, 135, 271-276. [CrossRef]

41. Acosta-Vigil, A. Estudio de los Fenómenos de Fusión Cortical y Generación de Granitoides Asociados a las Peridotitas de Ronda. Ph.D. Thesis, University of Granada, Granada, Spain, 1998.

42. Gómez-Ortiz, A.; Díaz del Olmo, F.; Simón-Torres, M. Periglaciarismo en las Cordilleras Béticas. In Periglaciarismo en la Península Ibérica, Canarias y Baleares. Estudios Significativos; Gómez-Ortiz, A., Simón-Torres, M., Salvador-Franch, F., Eds.; SEG-Universidad de Granada: Granada, Spain, 1994; pp. 165-188. ISBN 84-338-1982-8.

43. Sener, E.; Davraz, A.; Ozcelik, M. An integration of GIS and remote sensing in groundwater investigations: A case study in Burdur, Turkey. Hydrogeol. J. 2005, 13, 826-834. [CrossRef]

44. FAO-Organización de las Naciones Unidas para la Alimentación y la Agricultura. Base Referencial Mundial del Recurso Suelo 2014. Available online: http:/ / www.fao.org/3/i3794es/I3794es.pdf (accessed on 17 January 2018).

45. Bini, C.; Maleci, L.; Wahsha, M. Potentially toxic elements in serpentine soils and plants from Tuscany (Central Italy). A proxy for soil remediation. Catena 2017, 148, 60-66. [CrossRef]

46. Hseu, Z.-Y.; Zehetner, F.; Fujii, K.; Watanabe, T.; Nakao, A. Geochemical fractionation of chromium and nickel in serpentine soil profiles along a temperate to tropical climate gradient. Geoderma 2018, 327, 97-106. [CrossRef]

47. Aguilar, J.; Gómez, J.L.; Galán, E. Criterios y Estándares Para Declarar un Suelo Contaminado en Andalucía y la Metodología y Técnicas de Toma de Muestra y Análisis Para su Investigación; Consejería de Medio Ambiente de la Junta de Andalucía: Sevilla, Spain, 1999.

48. Suen, C.J. Geochemistry of Peridotites and Associated Mafic Rocks, Ronda Ultramafic Complex, Spain. Ph.D. Thesis, Massachusetts Institute of Technology, Cambridge, MA, USA, 2005; p. 283.

49. Visoli, G.; Menta, C.; Gardi, C.; Conti, F.D. Metal toxicity and biodiversity in serpentine soils: Application of bioassay tests and microarthropod index. Chemosphere 2013, 90, 1267-1273. [CrossRef] [PubMed]

50. U.S. EPA. Ecological Soil Screening Level for Iron. Interim Final OSWER Directive 9285.7-69. 2003. Available online: https://semspub.epa.gov/work/10/500006307.pdf (accessed on 11 February 2018).

51. Aguilar, J.; Calvo, R.; Fernández, E.; Macías, F. Geoquímica de la alteración y edafogénesis de rocas serpentinizadas de la Sierra Bermeja (Málaga). Edafología 1998, 5, 135-151.

52. Salminen, R. Geochemical Atlas of Europe. Available online: http://weppi.gtk.fi/publ/foregsatlas/ (accessed on 6 March 2018).

53. McKeague, J.A.; Wolynetz, M.S. Background levels of minor elements in some Canadian soils. Geoderma 1980, 24, 299-307. [CrossRef]

54. Mota, J.F.; Medina-Cazorla, J.M.; Navarro, F.B.; Pérez-García, F.J.; Pérez-Latorre, A.V.; Sánchez-Gómez, P. Dolomite flora of the Baetic Ranges glades (South Spain). Flora 2008, 203, 359-375. [CrossRef]

55. Rufo, L.; Rodríguez, N.; Fuente, V. Análisis comparado de metales en suelos y plantas de la Sierra Bermeja. In Proceedings II Simposio Nacional de Control de la Degradación de Suelos; Jiménez, R., Álvarez, A.M., Eds.; Universidad Autónoma de Madrid: Madrid, Spain, 2005; pp. 197-201. ISBN 84-689-2620-5.

56. Yusta, A.; Berahona, E.; Huertas, F.; Reyes, E.; Yáñez, J.; Linares, J. Geochemistry of soils from peridotite in Los Reales, Málaga. Acta Mineral. Petrog. 1985, 29, 439-498.

57. Olmedo-Cobo, J.A.; Cunill-Artigas, R.; Martínez-Ibarra, E.; Gómez-Zotano, J. Nuevos datos paleoecológicos de Abies ssp. en el Sur de España a partir del análisis pedoantracológico en Sierra Bermeja. In Avances en Biogeografía. Áreas de Distribución: Entre Puentes y Barreras; Gómez-Zotano, J., Arias-García, J., Olmedo-Cobo, J.A., Serrano-Montes, J.L., Eds.; Universidad de Granada-Tundra Ediciones: Granada, Spain, 2016; pp. 582-591. ISBN 978-84-338-5932-7.

58. Rieuwerts, J.S.; Thornton, I.; Farago, M.E.; Ashmore, M.R. Factors influencing metal bioavailability in soils: preliminary investigations for the development of a critical loads approach for metals. Chem. Speciat. Bioavailab. 1998, 10, 61-75. [CrossRef]

59. Alloway, B.J. Heavy Metals in Soils, 2nd ed.; Blackie Academic \& Professional: London, UK, 1995; ISBN 978-94-010-4586-5.

60. Boletín Oficial de la Junta de Andalucía-BOJA. Available online: http://normativa.infocentre.es/sites/ normativa.infocentre.es/files/noticies/20206012.pdf (accessed on 22 February 2018). 
61. Rufo, L.; de la Fuente, V.; Sánchez-Mata, D.; Rodríguez-Rojo, M.P. Studies on Iberian peninsula ultramafic flora: A selected nickel accumulation screening. Lazaroa 2004, 25, 161-167.

62. Alados-Arboledas, L.; Olmo, F.J.; Alados, I.; Pérez, M. Parametric models to estimate photosynthetically active radiation in Spain. Agric. Forest Meteorol. 2000, 101, 187-201. [CrossRef] 